\title{
„DIMITRIE BRANDZA” BOTANIC GARDEN, POTENTIAL CENTRE FOR THE DISPERSAL OF INVASIVE PLANTS?
}

\author{
NAGODĂ Eugenia*, COMĂNESCU Petronela ${ }^{*}$, \\ ANASTASIU Paulina*
}

\begin{abstract}
Botanic gardens are important centres for the conservation of plant diversity, but at the same time they can be responsible for plant invasions. As such it is paramount that botanic gardens evaluate their collections of exotic plants, monitor them and seek to minimise the risk of some species becoming invasive. In this context an evaluation of the collection of woody plants in the „Dimitrie Brandza” Botanic Garden, Bucharest, Romania was carried out, and it was established that although there are over 70 species with invasive potential, these do not represent a source of dispersal as the botanic garden is surrounded by artificial habitats undergoing regular maintenance. Nevertheless, indirectly, the Botanic Garden might have contributed to the process of invasion of some species as over the years it has offered vegetal material of plants known as invasive in international exchanges with other botanic gardens and even to the general public for private gardens.
\end{abstract}

Key words: botanic garden, naturalisation, tree invasions

Received 13 September 2014

Revision accepted 27 October 2014

\section{Introduction}

Botanic gardens are widely recognised as vital centres for biodiversity conservation (Marris 2006, Havens et al. 2006, Oldfield 2009, quoted in Hulme 2011). They contain in their collection a great variety of plants from various climate zones. It is estimated that around 30 to $40 \%$ of the known plant species are found in the living plant collections of the more than 2,500 botanic gardens and arboretums in the world (Kramer $\&$ Hird 2011). Most plants were introduced for decorative purposes, while others for education, research and conservation (Husby et al. 2010, Reichard \& White 2001, Hulme 2007, quoted by Heywood 2008). Some of these respond positively to climate changes and adapt easily to the new living conditions (Primarck \& Miller-Rushing 2009, Hulme 2011), or have certain traits that make them become invasive (Heywood \& Sharrock 2013). Naturalisation is a key stage in the process of invasion, and is influenced by the complex interplay of key factors that vary from species to species (Pyšek \& Richardson 2006, Richardson \& Pyšek 2006). The likelihood of naturalisation increases for those species with high tolerance to cold, with a wider area of origin and a wider planting frequency in botanic gardens (Hanspach et al. 2008).

\footnotetext{
*University of Bucharest, Botanic Garden “D. Brandza”, Şos. Cotroceni 32, Sector 6, 060114-Bucharest, Romania, e-mail: eugenia_nagoda@yahoo.com

${ }^{* * *}$ University of Bucharest, Faculty of Biology, Department of Botany \& Microbiology, Intr. Portocalelor 1-3, Sector 6, 060101-Bucharest, Romania.
} 
There is significant evidence showing that botanic gardens play a role in the introduction and spread of invasive species (Hulme 2011, Zuhri \& Mutaqien 2013). This has prompted the European Consortium of Botanic Gardens (2009) to advise that botanic gardens should evaluate their own collections as regards the risk of some species becoming invasive, to distribute information about their experience in tackling invasive species, to develop and implement guides, codes of conduct, best practice to prevent the spread of alien invasive species, to conduct research on the spread, control, management and the risk posed by invasive species. Botanic gardens ought to minimise the risk of plant invasions by monitoring their plant collections and evaluating the invasive potential of the species introduced (Lechner \& Kiehn 2010), identifying the means of introduction and the methods of control/eradication (Oldfield 2011, Kramer \& Hird 2011, Heywood \& Sharrock 2013).

Some important steps towards the evaluation of plant collections in terms of the risk of species becoming invasive have been taken in Central Europe (Galera \& SudnikWójcikowska 2010). The data analysed by the two authors have shown that botanic gardens do not represent a serious threat for the flora of Europe. The alien plant species escaped from culture do not have access to a wide array of habitats in the vicinity of gardens as the majority of botanic gardens are located in the city centre (Kowarik 2003). Therefore, the study suggests, botanic gardens do not represent a source of invasive species, but can play a role in the initial stage of the migration of invasive species (Galera \& Sudnik-Wójcikowska 2010).

Some of the species known as having escaped from European botanic gardens are Elodea canadensis Michx. (Berlin Botanic Garden), Impatiens parviflora DC. (Botanic Gardens of Dresden and Geneva), Senecio squalidus L. (Oxford University Botanic Garden), Heracleum mantegazzianum Sommier \& Levier and Heracleum persicum Desf. (Royal Botanic Gardens, Kew), Oxalis pes-caprae L. (Malta Botanic Garden), Cardamine corymbosa Hook.f. (Royal Botanic Garden, Edinburgh) (Heywood \& Sharrock 2013).

As regards botanic gardens in Romania there are some mentions of plants escaped from culture, but no comprehensive studies. Țopa $(1947,1956)$ notes the following species as having escaped from "A. Borza" Botanic Garden, Cluj-Napoca: Solanum nigrum L. subsp. humile Bernh., Reynoutria japonica Houtt. and Phytolacca acinosa Roxb.. Similarly, Duchesnea indica (Jacks.) Focke is recorded as subspontaneous in Iaşi and is considered to have escaped from "Anastasie Fătu" Botanic Garden (Godvinschi 1949).

In Bucharest, a city with a distinguished, 150 year-old botanic garden, there are to date no mentions of exotic plants that might have escaped from collections. However there are some studies concerning the acclimatisation and naturalisation of some exotic species (Tarnavschi \& Diaconescu 1958, 1960, 1961, 1965, Dihoru \& Rădulescu-Ivan 1960, Diaconescu 1978, Anastasiu 1994). Some of the woody species recorded as naturalised are Acer negundo L., Parthenocissus quinquefolia (L.) Planch., Lonicera tatarica L., Symphoricarpos albus (L.) S.F. Blake (Dihoru \& Rădulescu-Ivan 1960), Buxus sempervirens L., Ailanthus altissima (Miller) Swingle, Catalpa bignonioides Walter, Catalpa ovata G.Don, Catalpa speciosa (Warder ex Barney) Warder ex Engelm., Celtis occidentalis L., Gleditsia triacanthos L., Juglans nigra L., Ptelea 
trifoliata L. (Tarnavschi \& Diaconescu 1961), Hibiscus syriacus L., Berberis aquifolium Pursh, Viburnum rhytidophyllum Hemsl. (Anastasiu 1994).

Morariu (1937, 1941, 1944, 1960) noted the presence of some adventive plants in Bucharest, but none of these species are considered to have escaped from the collections of the Botanic Garden. Negrean \& Constantin (1999) also recorded new adventive plants in the flora of Bucharest, but only one of them is thought by the authors to have escaped from the Botanic Garden - namely Periploca graeca L., a liana considered to be native to Romania by other authors (Țopa 1961).

Special attention has been given globally to woody species as invasive species. These have a significant impact on biodiversity, on the well-functioning of ecosystems and on the lives of people in numerous regions of the world (Richardson et al. 2014). There are currently hundreds of studies documenting different aspects of the invasion of woody species, but as interest in these plants grows so does the complexity and magnitude of the challenges posed by their invasion (Richardson et al. 2014).

In this context we are bound to ask some questions about the botanic garden in Bucharest, Romania: (1) What is the current status of the exotic woody species cultivated in the Botanic Garden? (2) How many of these species are naturalised? (3) Are there in the collections of the Botanic Garden any woody species that have an invasive potential and might escape? (4) Are there any woody species in Bucharest and its surroundings that have escaped from the Botanic Garden? Has the Botanic Garden ever been or is it currently a source of plant invasions? This evaluation of the collection of exotic woody species in the „D. Brandza” Botanic Garden is in line with the recommendation of the fifth European Congress of Botanic Gardens regarding the evaluation of botanic gardens' own collections in order to identify those species with invasive potential (European Consortium of Botanic Gardens 2009).

\section{Material and methods}

Study area. "Dimitrie Brandza" Botanic Garden, stretching over an area of around 18 hectares, is located in the West side of Bucharest, on the right bank of the river Dâmbovița, at an altitude of 73-88 $\mathrm{m}$ (Fig. 1). The geographic coordinates for the central area of the Botanic Garden are: N44.437847 ${ }^{\circ}$ E029.063643 ${ }^{\circ}$. The relief is typical of the plain regions, the soil is alluvial, and climate is temperate continental, with slightly excessive tendencies (Sârbu \& Anastasiu 2001). The average annual rainfall for the period $1901-2000$ is $567.7 \mathrm{~mm} / \mathrm{mp}$, and the annual average temperature of the same period is $11^{\circ} \mathrm{C}$. The highest temperature was $42.4^{\circ} \mathrm{C}(2000)$, and the lowest temperature was $-30^{\circ} \mathrm{C}$ (1942) (Andrei 2013). According to „Winterhärtezoneneinteilung für Mitteleuropa” (Heinze \& Schreiber, MMDG, vol. 75, quoted by Erhardt et al. 2008), Bucharest is located in the climate zone 6, with minimum temperatures during winter of between -23.3 and $-17.8^{\circ} \mathrm{C}$. 


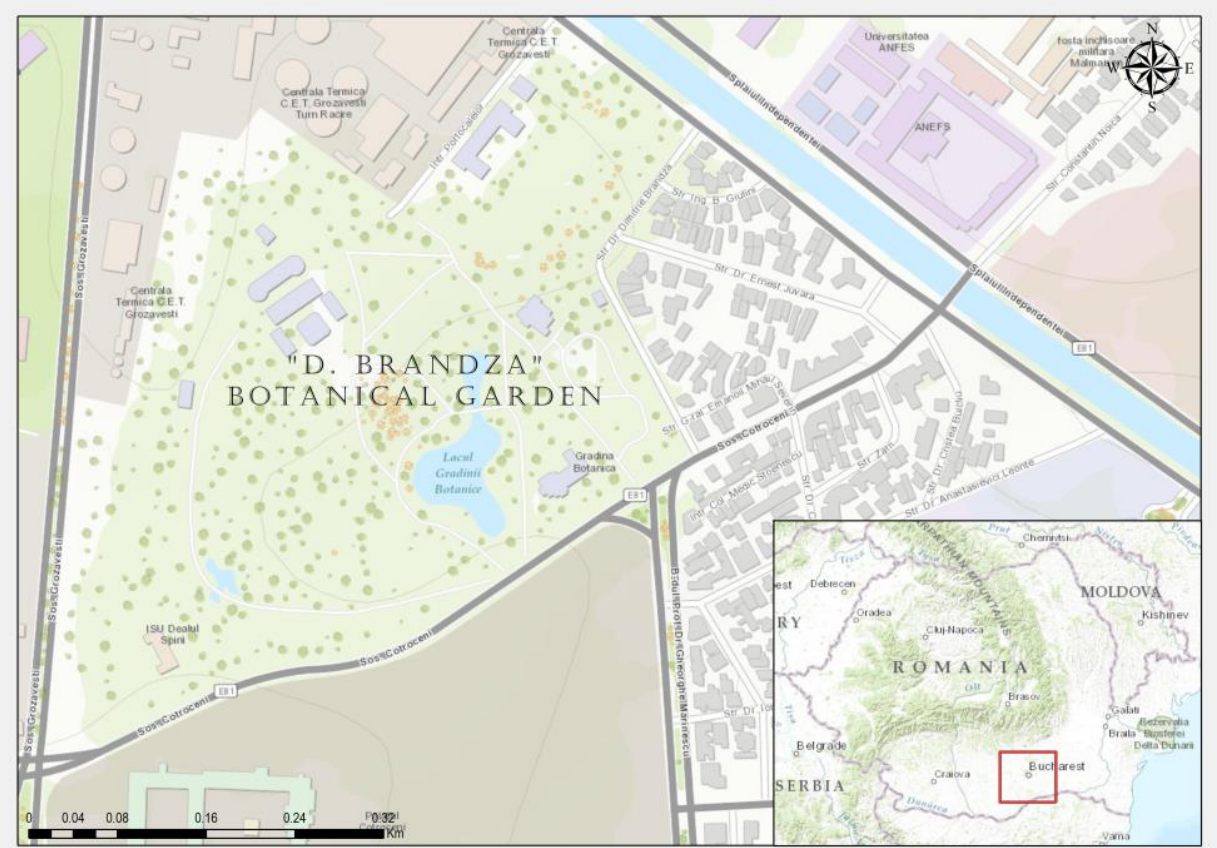

Fig. 1. The study area - Botanic Garden "Dimitrie Brandza" located in Bucharest, Romania (map compiled by Tiberiu Sahlean)

Material. For the purpose of this study, 195 exotic woody taxa cultivated in outdoor areas of the Botanic Garden were selected. Trees, shrubs and woody climbers cultivated between 1890 and 1970 were chosen for the study, as these offer the certainty of correct identification. It is worth mentioning here that the total inventory of the „D. Brandza" Botanic Garden includes just over 2,500 taxa, herbaceous and woody plants, of which about 1,000 are cultivated in the greenhouses, while the remaining 1,500 are cultivated outdoors.

The 195 species considered for this study belong to 57 families (Annex 1). The most representative families are: Rosaceae with 19 taxa (9.74\%), Leguminosae and Pinaceae with 16 taxa each (8.20\%), Caprifoliaceae, Cupressaceae and Sapindaceae with 10 taxa each (6.17\%), Magnoliaceae and Oleaceae with 7 taxa each (3.58\%), Moraceae with 6 taxa (3.07\%), Hamamelidaceae and Hydrangeaceae with 5 taxa each $(2.56 \%)$. Other 46 families included in this study have between one and four representatives, the largest share of these families having only one representative (21 families $-36.84 \%$ of the total of those included in the study).

In terms of native distribution, the largest share of woody plants analysed are of Asian origin, especially Chinese and Japanese (104 species - 53.33\%) (Annex 1). These are followed by North American species (62 taxa - 31.79\%) and by species of Mediterranean origin (24 taxa-12.30\%) (Fig. 2). 


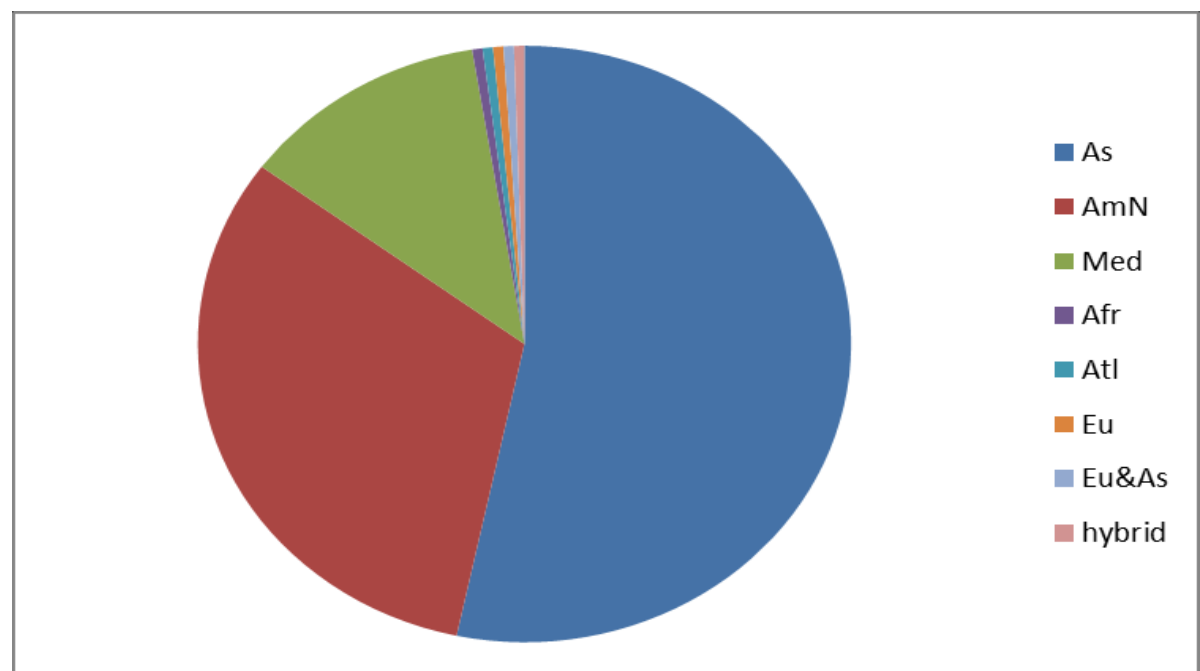

Fig. 2. The spectrum of the studied geoelements (As - Asian, AmN - North American, Med - Mediterranean, Afr - Afrikan, Atl - Atlantic, Eu - European)

Methods. For each taxa we conducted observations regarding the main phenophases (emergence of leaves, flowers and fruit), as well as an analysis of those aspects related to multiplication in the conditions available at the Botanic Garden. Based on the data obtained, the status of the species was assessed on a scale from 1 to 4 as follows: 1 - the species survives in the climatic conditions of the Botanic Garden, but it does not flower; 2 - the species survives in the climatic conditions of the Botanic Garden, it flowers but does not bear fruit; 3 - the species survives in the climatic conditions of the Botanic Garden, it flowers, bears fruit, produces seeds but the seeds do not germinate in the absence of human intervention; 4 - the species survives in the climatic conditions of the Botanic Garden, it flowers, bears fruit and produces seeds and seedlings around the parent plant, without any human intervention.

According to Săvulescu (1949), the first two statuses correspond to the accommodation stage, the third status corresponds to the acclimatisation stage, and the fourth stage to the naturalisation stage. For each of the four statuses mentioned above we conducted comparative analyses of their status in Romania (according to Anastasiu \& Negrean 2009, Sîrbu \& Oprea 2011), in Europa (according to DAISIE 2008, Křivánek \& Pyšek 2006) and globally, according to the Global Compendium of Weeds (Randall 2011) and Richardson \& Rejmanek (2011) (Annex 1). We also included in our study the surrounding areas of the Botanic Garden in order to identify possible taxa escaped from culture.

Numerous tools for the evaluation of the risk of invasion/ invasiveness have been created and are available (Reichard \& Hamilton 1997, Pheloung et al. 1999, Weber \& Gut 2004, Křivánek \& Pyšek 2006, Husby et al. 2010, Richardson \& Rejmánek 2011). Given that ,one of the best predictors of the invasiveness of introduced species is whether they have invaded in other parts of the world" (Richardson \& Rejmánek 2011), we considered as potentially invasive those taxa already known to have these capabilities in other areas of the world, correlated at the same time with their status in 
the „D. Brandza” Botanic Garden. The nomenclature of the species considered in this study is according to The Plant List (www theplantlist.org).

Abbreviations used in the Annex 1: Native range: Am - America, Afr - Africa, As - Asia, Balk - Balkanic, Eu - Europe, Medit - Mediterranean, USA - United State of America, N - Nord, E - East, S - South, W - West, C - Central; subtrop. subtropical, temp. - temperate; Status in Botanic Garden "D. Brandza": 1 - the species survives in the climatic conditions of the Botanic Garden, but it does not flower; 2 - the species survives in the climatic conditions of the Botanic Garden, it flowers but does not bear fruit; 3 - the species survives in the climatic conditions of the Botanic Garden, it flowers, bears fruit, produces seeds but the seeds do not germinate in the absence of human intervention; 4 - the species survives in the climatic conditions of the Botanic Garden, it flowers, bears fruit and produces seeds and seedlings around the parent plant, without any human intervention; Status in Romania: 0 - not included in list of alien plants, $\mathrm{c}$ - casual, $\mathrm{n}$ - naturalised, $\mathrm{n}$ - invasive, subspont. - subspontaneous, cult. cultivated; Status in DAISIE: A - alien to Europe, E - alien in Europe; Compendium of weeds: 0 - absent, 1 - present; Others: ne - not evaluated; AtlIs - Atlantic Islands, Aus - Australia, PacIs - Pacific Islands, Zee - New Zealand; CR - Czech Republic; WRA - Weed Risk Assessment.

\section{Results and discussion}

The observations made on the 195 taxa studied highlight the existence in the collection of woody plants of the „D. Brandza” Botanic Garden of plants that have not got beyond the accommodation stage, but also of plants that are fully naturalised and even have invasive potential.

Thus two of the 195 taxa analysed survive and have a very good growth in the conditions of the „D. Brandza” Botanic Garden, but they do not flower (Magnolia grandiflora) or form cones (Metasequoia glyptostroboides). Magnolia grandiflora is included on the list of alien plants in Europe (DAISIE 2008) and both species are listed in the Global Compendium of Weeds with different statuses (naturalised for Magnolia grandiflora and environmental weed for Metasequoia glyptostroboides). So far these two species have not been reported in Romania as naturalised or even escaped from culture, and have not been included on the list of species evaluated for invasive risk in Central Europe or globally (Křivánek \& Pyšek 2006, Richardson \& Rejmánek 2011).

23 taxa belong to the second category - that of species that flower, but do not bear fruit or do not form cones (Annex 1). Half of these taxa originate from Asia, while around $30 \%$ of the species are of American origin. The remaining species, around 20\%, come from Southern Europe, Northern Africa or are present in both Europe and Asia. Of the total of 23 taxa of this category, only Gymnocladus dioica is mentioned at national level as naturalised (Sîrbu \& Oprea 2011). In the „D. Brandza” Botanic Garden only masculine specimens are cultivated, so there is no question of fruit formation. At European level, 15 taxa of this category are on the list of alien species (DAISIE 2008), and Prunus laurocerasus is mentioned as escaped from cultivation for the Czech Republic (Křivánek \& Pyšek 2006) and is on the list of invasive species at global level in North America, Europe and Australia (Richardson \& Rejmánek 2011). In the „D. Brandza" Botanic Garden vegetative propagation was not observed in any of the species of this category. 
125 taxa fall into the third category - that of species that flower, produce cones or fruit, produce seeds, but do not germinate without human intervention in the environment of the „D. Brandza” Botanic Garden. Of these taxa, 74 are of Asian origin and some of them have been reported in Romania as being occasional/ subspontaneous or even naturalised (Anastasiu \& Negrean 2009, Sîrbu \& Oprea 2011): Buddleja davidii, Caragana arborescens, Chaenomeles japonica, Elaeagnus angustifolia, Ginkgo biloba, Lycium barbarum, Parthenocissus tricuspidata, Phellodendron amurense, Punica granatum, Platycladus orientalis, Sorbaria sorbifolia and Spiraea japonica. Lycium barbarum is considered invasive in Romania (Anastasiu \& Negrean 2009), and in Europe (Křivánek \& Pyšek 2006, Richardson \& Rejmánek 2011), as well as Elaeagnus angustifolia and Sorbaria sorbifolia (Křivánek \& Pyšek 2006). Globally these are considered to be: ,agricultural weed, casual alien, cultivation escape, environmental weed, garden thug, naturalised, noxious weed, sleeper weed, weed" for Buddleja davidii, ,,agricultural weed, casual alien, cultivation escape, environmental weed, garden thug, naturalised, weed” for Caragana arborescens, ,,agricultural weed, casual alien, cultivation escape, environmental weed, garden thug, naturalised, noxious weed, weed" for Elaeagnus angustifolia, ,agricultural weed, casual alien, cultivation escape, environmental weed, garden thug, naturalised, weed " for Lycium barbarum, „environmental weed, naturalised, noxious weed, weed" for Phellodendron amurense, „casual alien, cultivation escape, environmental weed, garden thug, naturalised” for Sorbaria sorbifolia and „casual alien, cultivation escape, environmental weed, garden thug, naturalised, weed" for Spiraea japonica (Randall 2011).

Although Buddleja davidii is considered,a serious invader in Australia, Mediterranean basin, and European regions with oceanic climate" (Weber 2003, quoted by Křivánek \& Pyšek 2006), in the „D. Brandza” Botanic Garden its seeds do not germinate. It is likely that the cold climate of Bucharest, with winter temperatures often below $0^{\circ} \mathrm{C}$, is not favourable to the naturalisation of this species. An interesting case is that of Lycium barbarum and Elaeagnus angustifolia for which there are no records of juvenile specimens in the Botanic Garden. Sorbaria sorbifolia, a plant naturalised and potentially invasive in the Czech Republic (Křivánek \& Pyšek 2006) and invasive in Europe (Richardson \& Rejmánek 2011) falls under the same category of woody species that are not fully naturalised in the „D. Brandza” Botanic Garden. It is worth mentioning that Sorbaria sorbifolia was identified as occasional around the Port of Constanța, Romania (Anastasiu et al. 2009).

Another important group of the third category is that of species of American origin, comprising of 37 species. Nationally 13 species of this group are considered subspontaneous or naturalised (Annex 1), while Fraxinus pennsylvanica was recently reported as invasive in the Danube Delta (Anastasiu et al. 2013). With the exception of Hibiscus moscheutos, all the species are also considered alien in or to Europe (DAISIE 2008). Four of them are already invasive in Europe: Fraxinus pennsylvanica, Pinus strobus, Quercus rubra, Rhus typhina (Křivánek \& Pyšek 2006), and 9 are evaluated as invasive globally: Acer saccharinum, Fraxinus americana, Fraxinus pennsylvanica, Juniperus virginiana, Maclura pomifera, Pinus strobus, Pseudotsuga menziesii, Quercus rubra, Rhus typhina (Richardson \& Rejmánek 2011). In the „D. Brandza” 
Botanic Garden, of the 37 American species in the third category, only Rhus typhina features vegetative propagation, with numerous plant suckers around the mother plant.

A small number of exotic woody species that get to bear fruit, but do not multiply without human intervention come from areas closer to Romania, such as South-Western and Southern Europe, and in some cases the Mediterranean and the South of Russia: Abies cephalonica, Castanea sativa, Ficus carica, Ilex aquifolium, Lonicera caprifolium, Lonicera tatarica, Mespilus germanica, Philadelphus coronarius, Pinus nigra subsp. austriaca, Pyracantha coccinea, Ribes rubrum, Spartium junceum and Spiraea hypericifolia. Some of them were reported as subspontaneous or naturalised in Romania (Lonicera caprifolium, Mespilus germanica, Philadelphus coronarius, Ribes rubrum, Spiraea hypericifolia) (Anastasiu \& Negrean 2009, Sîrbu \& Oprea 2011), but none are mentioned as invasive. Notwithstanding, for Europe Richardson \& Rejmánek (2011) included on the list of invasive species Pinus nigra subsp. austriaca and Pyracantha coccinea, and at global level they included Ilex aquifolium, Lonicera tatarica, Spartium junceum (Richardson \& Rejmánek 2011).

There are 45 species (Annex 1) falling under the fourth category - that of species that flower, bear fruit and produce seedlings around the mother plant without any human intervention (naturalised). 21 of these species are of Asian origin. While some of them have not been reported in Romania even as subspontaneous (e.g. Alangium platanifolium, Celastrus orbiculatus, Smilax excelsa), others are already known as invasive (Ailanthus altissima) or naturalised (Morus alba, Morus nigra) (Anastasiu \& Negrean 2009). Only three of the species of this category are not on the DASIE (2008) list: Alangium platanifolium, Cudrania tricuspidata and Desmodium stenophyllum. At European and global level the following species are considered to be invasive: Ailanthus altissima, Albizia julibrissin, Broussonetia papyrifera, Morus alba, Paulownia tomentosa and Salix babylonica (Richardson \& Rejmánek 2011). There are 18 naturalised species of American origin, three of which are known as invasive in Romania: Acer negundo, Amorpha fruticosa, Robinia pseudoacacia (Anastasiu \& Negrean 2009). Four other American species are reported as naturalised in Romania: Catalpa bignonioides, Gleditsia triacanthos, Parthenocissus inserta and Ulmus pumila (Anastasiu \& Negrean 2009). A re-evaluation of these species would undoubtedly show that Parthenocissus inserta is invasive, especially considering its spread in the past few years and its frequent presence in the habitats on waters' edges (Anastasiu, unpubl.). In fact, this species is considered invasive in the Czech Republic (Křivánek \& Pyšek 2006). From the group of naturalised species in the „D. Brandza” Botanic Garden, the following species are considered invasive in Europe: Acer negundo, Amorpha fruticosa, Berberis aquifolium, Parthenocissus inserta, Robinia pseudoacacia and Symphoricarpos albus (Richardson \& Rejmánek 2011). Globally, three further species are considered invasive: Celtis occidentalis, Gleditsia triacanthos and Ulmus pumila (Richardson \& Rejmánek 2011). There are only a handful of species from Southern Europe and North Africa naturalised in the „D. Brandza” Botanic Garden: Aesculus hippocastanum, Buxus sempervirens, Cercis siliquastrum, Periploca graeca and Platanus acerifolia. With the exception of Periploca graeca, considered by some authors as native to South Romania (T,opa 1961), all the other species were reported as subspontaneous or naturalised in Romania (Anastasiu \& Negrean 2009, Sîrbu \& Oprea 
2011). None of the species in this sub-category are considered invasive in Europe or on another continent.

This category of plants naturalised in the Botanic Garden can represent a source of plant invasions in Bucharest and surrounding areas. The species already recognised as invasive in Romania (Ailanthus altissima, Acer negundo, Amorpha fruticosa, Robinia pseudoacacia), might be joined by new species currently considered invasive in Europe or globally (Albizzia julibrissin, Broussonetia papyrifera, Celtis occidentalis, Gleditsia triacanthos, Lonicera japonica, Berberis aquifolium, Morus alba, Paulownia tomentosa, Symphoricarpos albus, Ulmus pumila). Furthermore, we consider to be potentially invasive a number of species currently included in the third category, that of species that do not generate new individuals, although they produce fruit and seeds: Acer saccharinum, Berberis thunbergii, Buddleja davidii, Caragana arborescens, Castanea sativa, Catalpa bignonioides, Cotoneaster horizontalis, Elaeagnus angustifolia, Fraxinus pennsylvanica, Fraxinus americana, Juniperus virginiana, Lonicera tatarica, Lycium barbarum, Maclura pomifera, Parthenocissus tricuspidata, Pinus nigra subsp. austriaca, Pinus strobus, Populus $\times$ canadensis, Pyracantha coccinea, Quercus rubra, Rhus typhina, Ribes aureum, Sorbaria sorbifolia, Spiraea japonica, Pseudotsuga menziesii. These have been reported as naturalised or even invasive in Europe or on other continents (Annex 1). What is more, some of the species above have already been noted as subspontaneous in the different regions of the country, despite not being reported as naturalised to date. For example, Pinus nigra subsp. austriaca is frequently subspontaneous in areas in Dobrogea where it has previously been cultivated on degraded lands (Anastasiu, unpubl.). Juniperus virginiana, cultivated as a decorative species, is also subspontaneous in Dobrogea and even the Danube Delta (Anastasiu, unpubl.). Thus the list of potentially invasive species in the „D. Brandza” Botanic Garden comprises of 73 species (Annex 1).

The research conducted in the surrounding areas of the „D. Brandza” Botanic Garden revealed the presence of four species escaped from culture (Parthenocissus inserta, Morus alba, Paulownia tomentosa and Styphnolobium japonicum), helped by the mode of seed dispersal and the large number of individuals in the Botanic Garden. These were found in the cracks of pavements, along fences and lawns, along the banks of the river Dâmbovița, but only in the juvenile stage. They probably do not get to maturity due to regular maintenance work being done by the specialised staff authorised to carry out these works. As such we are of the view that the taxa escaped from cutivation from the Botanic Garden have no chance to become naturalised because they cannot find a suitable habitat for that due to being in an urban area regularly maintained. These findings are confirmed by the data in the literature (Kowarik 2003).

It is difficult to give a definitive answer to the question 'Has the „D. Brandza” Botanic Garden ever been or is it currently a source of plant invasions?' using the bibliographic data available. Species such as Ailanthus altissima and Amorpha fruticosa, widely spread across the country (Anastasiu \& Negrean 2009, Sîrbu \& Oprea 2011), were reported for the first time as escaped/ subspontaneous in Bucharest (Grecescu 1898), without any mention of the possible source. It is likely that Amorpha fruticosa escaped from the collections of the „D. Brandza” Botanic Garden given that it is mentioned as early as 1876 as being cultivate outdoors, together with seven other species of Amorpha (Grecescu 1876). Nonetheless the wide spread that the species 
currently enjoys is due to the fact that in the past it was used to a large extent for the afforestation of degraded lands, slopes and embankments (Iovu-Adrian Biriş, personal correspondence). As regards Ailanthus altissima, this does not appear in the catalogues of the Botanic Garden of that time, but the presence of the plant in photographs from the beginning of the twentieth century shows the existence of this plant in the central area of Bucharest, in Piața Victoriei (Majuru 2003: 119), not far from the place where the Botanic Garden was located from 1874 to 1884. Parthenocissus inserta is another species whose source of spread seems to have been the Botanic Garden. The first mention of this plant in Romania belongs to Grecescu (1876) which includes the plant in his „Catalogue of plants cultivated in the Botanic Garden of Bucharest between 1871 and 1875". As early as 1898 Parthenocissus inserta was mentioned as a naturalised plant (Grecescu 1898).

Indirectly, „D. Brandza” Botanic Garden can be seen as a source of the invasion of some woody species because over time it has offered for sale or exchange species known as invasive or potentially invasive such as: Acer negundo, Paulownia tomentosa, Spiraea japonica etc. This practice has stopped in more recent years, and the Botanic Garden is championing an ever growing role in raising awareness of the issues alien species are responsible for.

\section{Conclusions}

Of the total number of woody species investigated, only 45 are naturalised in the „D. Brandza” Botanic Garden. Some are already known to be invasive nationally or globally, while others can be considered to be potentially invasive, given their status in the Botanic Garden, and also at global level. We also consider as having invasive potential a series of species which, although not currently fully naturalised in the Botanic Garden, but merely acclimatised, have been reported as invasive in Europe or globally. The fact that the „D. Brandza” Botanic Garden is located in an area with no habitats favourable to the installation of some species already naturalised means that the Botanic Garden is not a direct source of plant invasions. Indirectly, by providing woody species, it could contribute to the spread of species already assessed as potentially invasive (Paulownia tomentosa, Albizia julibrissin, Celtis occidentalis, Broussonetia papyrifera), which is why it is necessary to implement the measures proposed by European Code of Conduct for Botanic Gardens on Invasive Alien Species ( Heywood \& Sharrock 2013).

Acknowledgements: We thank to Tiberiu Sahlean for the map of investigated area.

\section{References}

Anastasiu, P. \& Negrean, G. (2009). Neophytes in Romania. In L. Rákosy \& L. Momeu (coord.). Neobiota din România (pp. 66-97). Cluj-Napoca: Editura Presa Universitară Clujeană.

Anastasiu, P. (1994). Plante naturalizate în municipiul Bucureşti. Acta Botanica Horti Bucurestiensis, /1993-1994/, 135-137.

Anastasiu, P., Negrean, G., Făgărăş, M., Samoilă, C. \& Cogălniceanu, D. (2009). Constanța Harbour (Romania) as a major gateway and reservoir for alien plant species. Acta Horti Bot. Bucurest., 36, 41-60. 
Anastasiu, P., Negrean, G., Sârbu, A. \& Smarandache, D. 2013. Plante alohtone din Delta Dunării. In M. Doroftei \& S. Covaliov (eds). Manual de ... Delta Dunării. Ghid pentru personalul de teren al Administrației Rezervației Biosferei Delta Dunării şi Gărzii de Mediu (pp. 135-194). Tulcea: Editura Centrul de Informare Tehnologică Delta Dunării.

Andrei, T. (coord.) (2013). Anuarul statistic al României 2013 - Romanian Statistical Yearbook. Bucureşti: Institutul Naţional de Statistică.

DAISIE (2008). The handbook of alien species in Europe (eds. Hulme P., Netwig W., Pysek P. \& Vilà M.). Dordrecht-Heidelberg: Springer Publisher.

Diaconescu, V. (1978). Considérations sur le phénomenè de naturalisation des espèces exotiques ligneuses. Acta Botanica Horti Bucurestiensis, /1977-1978/, 51-57.

Dihoru, G. \& Rădulescu-Ivan, D. (1960). Observații asupra florei şi vegetaţiei spontane din Grădina Botanică Bucureşti. Acta Botanica Horti Bucurestiensis, /1959/, 55-85.

Erhardt, W., Götz, E., Bödeker, N. \& Seybold, S. (2008). Der grosse Zander. Enzyklopädie der Pflanzennamen. Stuttgart: Ulmer.

European Consortium of Botanic Gardens (2009). Resolutions of the Fifth European Botanic Gardens Congress. EuroGard V - Botanic Gardens in the age of Climate Change, Helsinki, Finland, 8-12 June, 2009.

Galera, H. \& Sudnik-Wójcikowska, B. (2010). Central European Botanic Gardens as centres of dispersal of alien plants. Acta Societatis Botanicorum Poloniae, 79(2), $147-156$.

Godvinschi, M. (1949). Câteva date floristice pentru oraşul şi județul Iaşi. Rev. Şti. " $V$. Adamachi”, 35(3-4), 182-183.

Grecescu, D. (1876). Catalogul plantelor cultivate în Grădina botanică din Bucureşti în cursul anilor 1871 până la 1875. Bucureşti: Noua tipografie a laboratorilor români.

Grecescu, D. (1898). Conspectul Florei României. Bucureşti: Tipografia "Dreptatea".

Hanspach, J., Kühn, I., Boos, E. \& Klotz, S. (2008). Correlates of naturalization and occupancy of introduced ornamentals in Germany. Perspectives in Plant Ecology, Evolution and Systematics, 10, 241-250.

Heywood, V.H. \& Sharrock, S. (2013). European Code of Conduct for Botanic Gardens on Invasive Alien Species. Council of Europe, Strasbourg, Botanic Gardens Conservation International, Richmond.

Heywood, V.H. (2008). A Code of Conduct on invasive alien species for Europe's Botanic Gardens. BGJournal, 8(2), 26-28.

Hulme, P.E. (2011). Addressing the threat to biodiversity from botanic gardens. Trends in Ecology and Evolution, 28(4), 168-174.

Husby, C.E., Liu, H. \& Reichard, S.H. (2010). Weed risk assessment for botanic garden decision making. Proceedings of the $4^{\text {th }}$ Global Botanic Gardens Congress, June 2010. Retrieved from: http://www.bgci.org/files/Dublin2010/papers/HusbyChad.pdf

Kowarik, I. (2003). Biologische Invasionen: neophyten und Neozonen in Mitteleuropa. Stuttgart: Verl. E. Ulmer.

Kramer, A. \& Hird, A. (2011). Building an International Sentinel Plant Network. BGJournal, 8(2), 3-6. 
Křivánek, M. \& Pyšek P. (2006). Predicting invasions by woody species in a temperate zone: a test of tree risk assessement schemes in the Czech Republic (Central Europe). Diversity and Distribution, 12, 319-327.

Lechner, M. \& Kiehn, M. (2010). Assessing invasive potentials of plant species cultivated in botanic gardens in Central Europe. Proceedings of the $4^{\text {th }}$ Global Botanic Gardens Congress, June 2010. Retrieved from: http://www.bgci.org/files/Dublin2010/papers/Lechner-Marian.pdf

Majuru, A. (2003). Bucureştii mahalalelor sau periferia ca mod de existent. Bucureşti: Compania.

Morariu, I. (1937). Periodicitate şi amestecuri antropogene în flora mărginaşă Bucureştilor. Revista Ști. "V. Adamachi”, 23(1), 46-48.

Morariu, I. (1941). Plante nouă sau rare în jurul Bucureştilor. Bul. Grăd. Bot. şi al Muzeului Botanic dela Univ. din Cluj, 20(3-4), 148-150.

Morariu, I. (1944). Plante nouă în flora Bucureștilor. Bul. Grăd. Bot. şi al Muzeului Botanic dela Univ. din Cluj, 24(1-2), 13-15.

Morariu, I. (1960). Câteva noutăți în flora Bucureştiului. Comunic. Acad. Rom., 10(3), 217-223.

Negrean, G., \& Constantin, N. (1999). Noi plante adventive în Flora Bucureştiului. Acta Botanica Horti Bucurestiensis, 27, 143-145.

Oldfield, S. (2011). Editorial: tackling invasive species. BGJournal, 8(2), 3.

Pheloung, P.C., Williams, P.A. \& Halloy, S.R. (1999). A weed risk assessement model for use as a biosecurity tool evaluating plant introductions. Journal of Environmental Management, 57, 239-251.

Primarck, R.B. \& Miller-Rushing, A.J. (2009). The role of botanical gardens in climate change research. New. Phytol., 182, 303-313.

Pyšek, P. \& Richardson, D.M. (2006). The biogeography of naturalization in alien plants. J. Biogeogr., 33, 2040-2050.

Randall, R.P. (Rod) (2011). Global Compendium of Weeds. Retrieved after $1^{\text {st }}$ January, 2014, from: www. hear.org

Reichard, S.H. \& Hamilton, C.W. (1997). Predicting Invasions of Woody Plants Introduced into North America. Conservation Biology, 1(1), 193-203.

Reichard, S.H. \& White, P. (2001). Horticulture as a pathway of invasive plant introduction the United States. BioScience, 51, 103-113.

Richardson, D.M. \& Pyšek, P. (2006). Plant invasions: merging the concepts of species invasiveness and community invasibility. Prog. Phys. Geogr., 30, 409-431.

Richardson, D.M. \& Rejmánek, M. (2011). Trees and shrubs as invasive alien species a global rewiew. Diversity and Distribution, 17, 788-809.

Richardson, D.M., Hui, C., Nuñez, M.A. \& Pauchard, A. (2014). Tree invasions: patterns, processes, challenges and opportunities. Biol Invasions, 16, 473-481, DOI 10.1007/s10530-013-0606-9.

Sârbu, A. \& Anastasiu, P. (2001). Grădina Botanică "Dimitrie Brandza" a Universităţii din București. In A. Sârbu (coord.), Asociația Grădinilor Botanice din România un pas spre integrarea europeană (pp. 23-38). Bucureşti: Edit. alo, Bucureşti!

Săvulescu, T. (1949). De la practica domesticirii plantelor, la principii biologice generale. Bucureşti. 
Sîrbu, C. \& Oprea, A. (2011). Plante adventive în flora României. Iaşi: Edit. "Ion Ionescu de la Brad".

Tarnavschi, I.T. \& Diaconescu, V. (1958). Câteva specii exotice naturalizate în R.P.România. Natura, 5, 68-78.

Tarnavschi, I.T. \& Diaconescu, V. (1960). Specii de plante lemnoase exotice rare, cultivate în Grădina Botanică din București. Acta Botanica Horti Bucurestiensis, /1959/, 37-55.

Tarnavschi, I.T. \& Diaconescu, V. (1961). Speciile de plante lemnoase exotice cultivate în Grădina Botanică din Bucureşti. Acta Botanica Horti Bucurestiensis, /1960/, 23-71.

Tarnavschi, I.T. \& Diaconescu, V. (1965). Câteva specii exotice naturalizate în Republica Socialistă România. Acta Botanica Horti Bucurestiensis, /19641965/, 19-26.

The Plant List (2010). Version 1. Retrieved after $1^{\text {st }}$ January, 2014, from: http://www.theplantlist.org

Țopa, E. (1961). Genul 495. Periploca L. In T. Săvulescu (red.), Flora Republicii Populare Române. II (pp.486-489). Bucureşti: Edit. Academiei Republicii Populare Române.

Țopa, E., (1947). Contribuțiuni noui la cunoaşterea ergasiophytelor din Cluj. Bul. Grăd. Bot. Cluj, 27(3-4), 181-188.

Țopa, E., (1956). Călăuza Grădinii Botanice din Cluj. Cluj-Napoca: Edit. Univ. "V. Babeş".

Weber, E. \& Gut, D. (2004). Assessing the risk of potentially invasive plant species in central Europe. Journal for Nature Conservation, 12, 171-179.

Zuhri, M. \& Mutaquien, Z. (2013). The spread of Non-native Plant Collection of Cibodas Botanical Garden into Mt. Gede Pangrango National Park. The Journal of Tropical Life Science, 3(2), 74-82. 


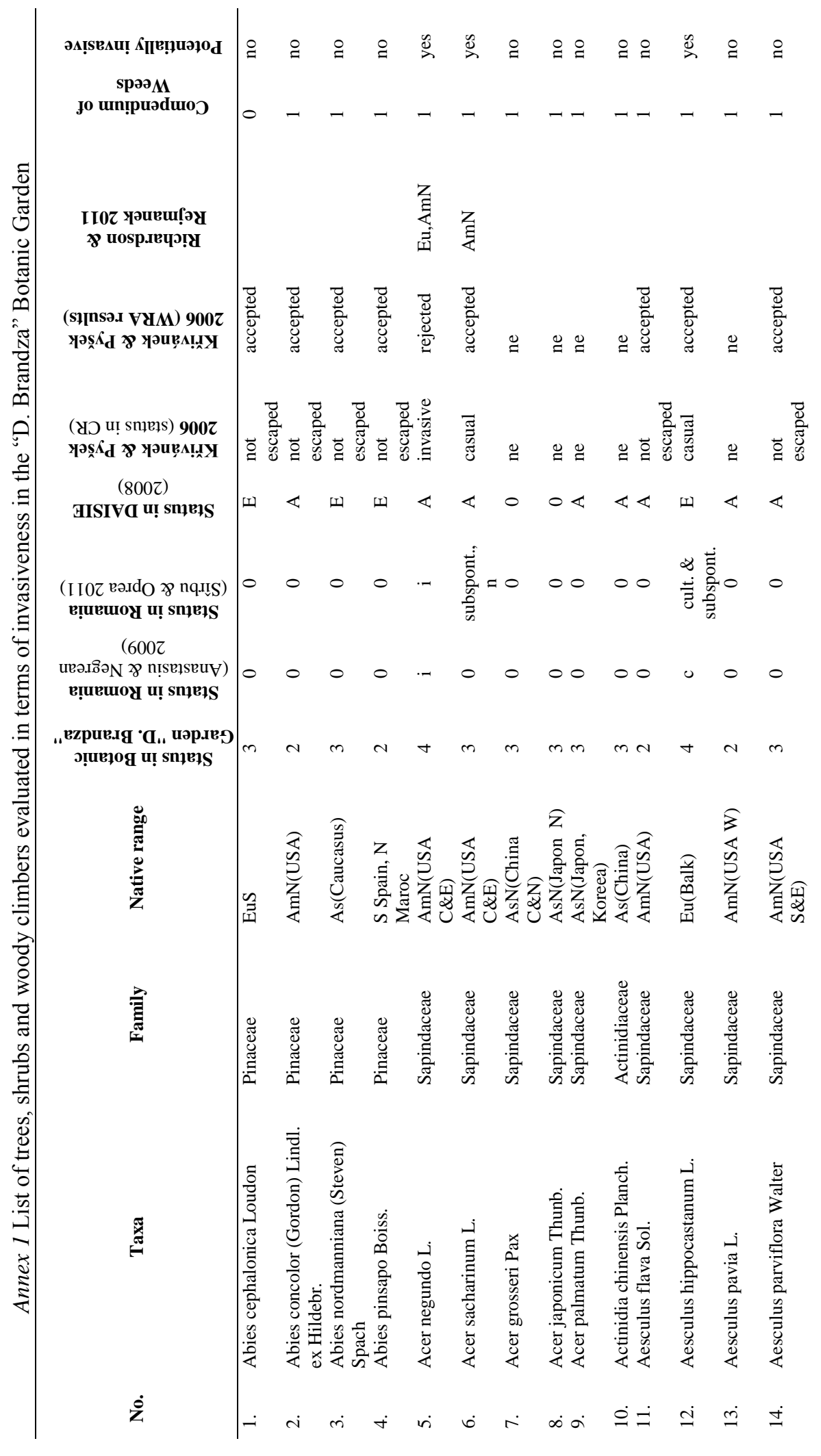




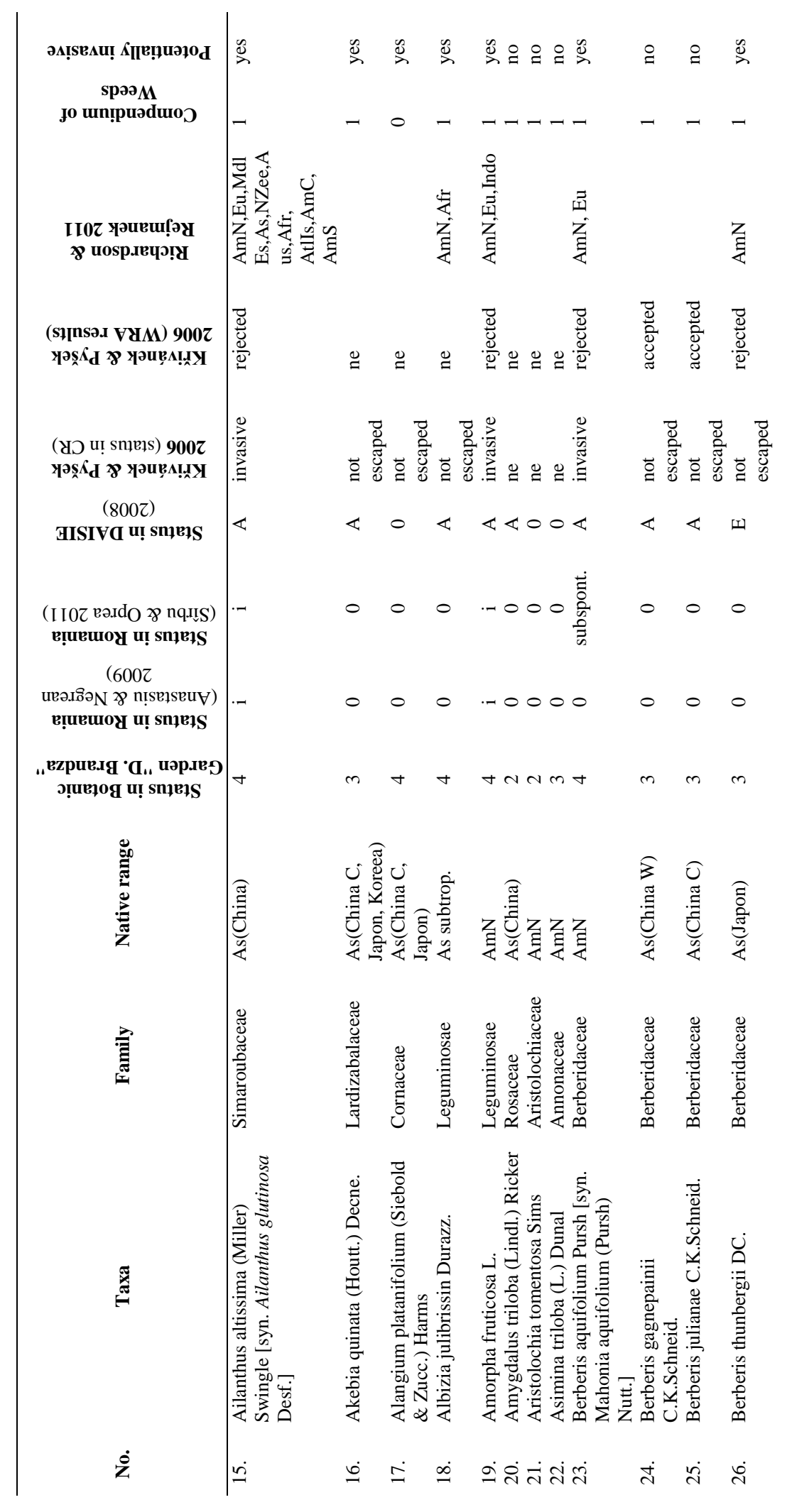




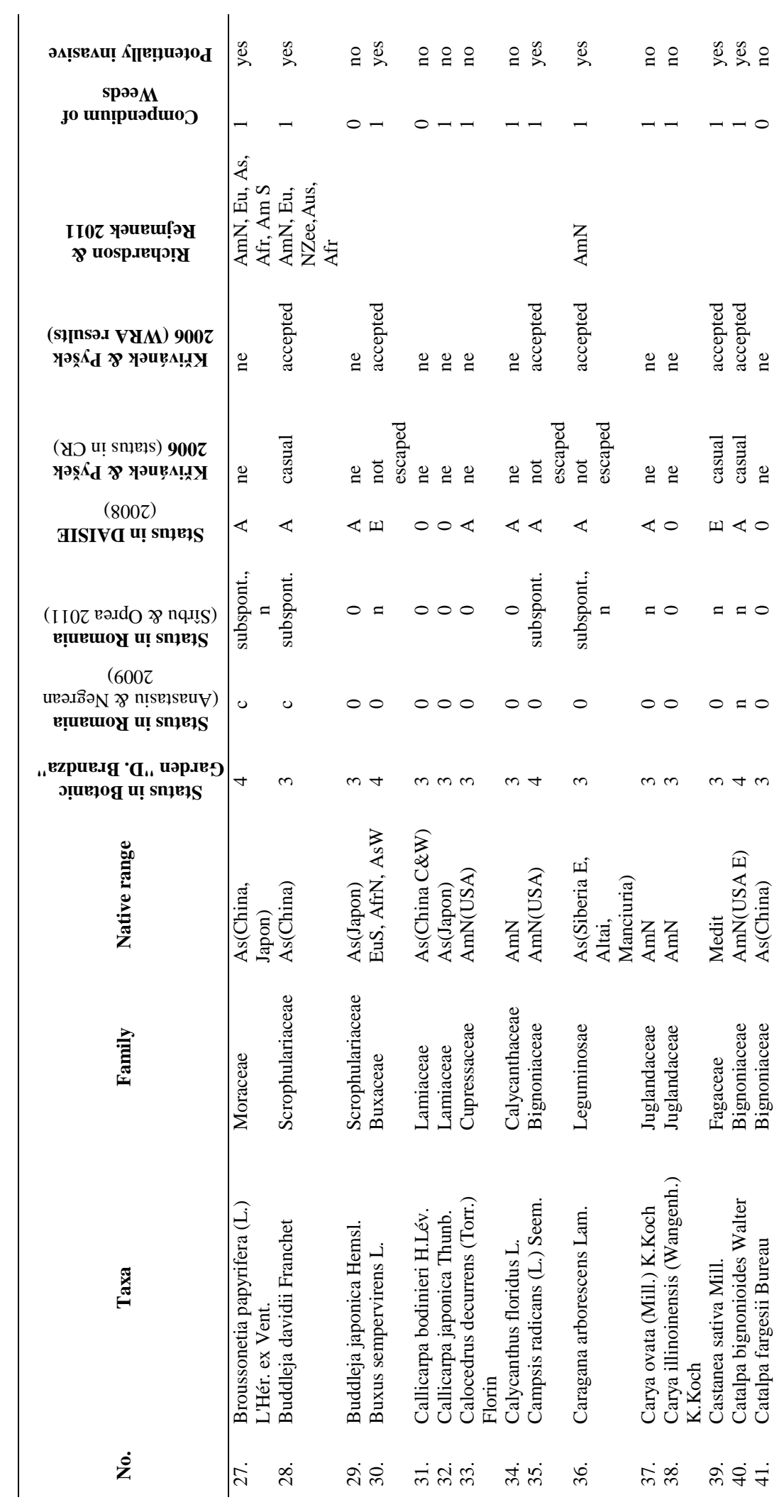




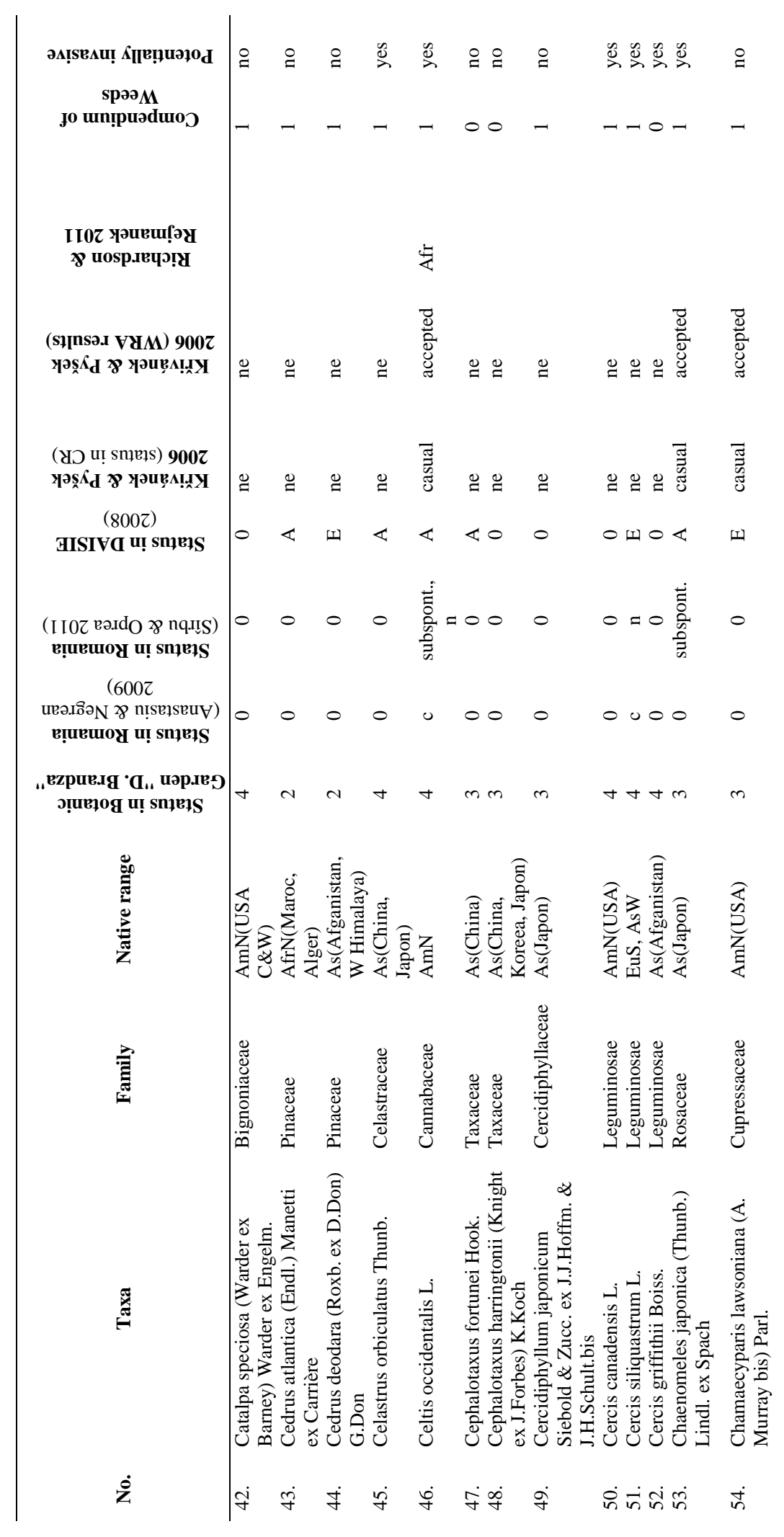




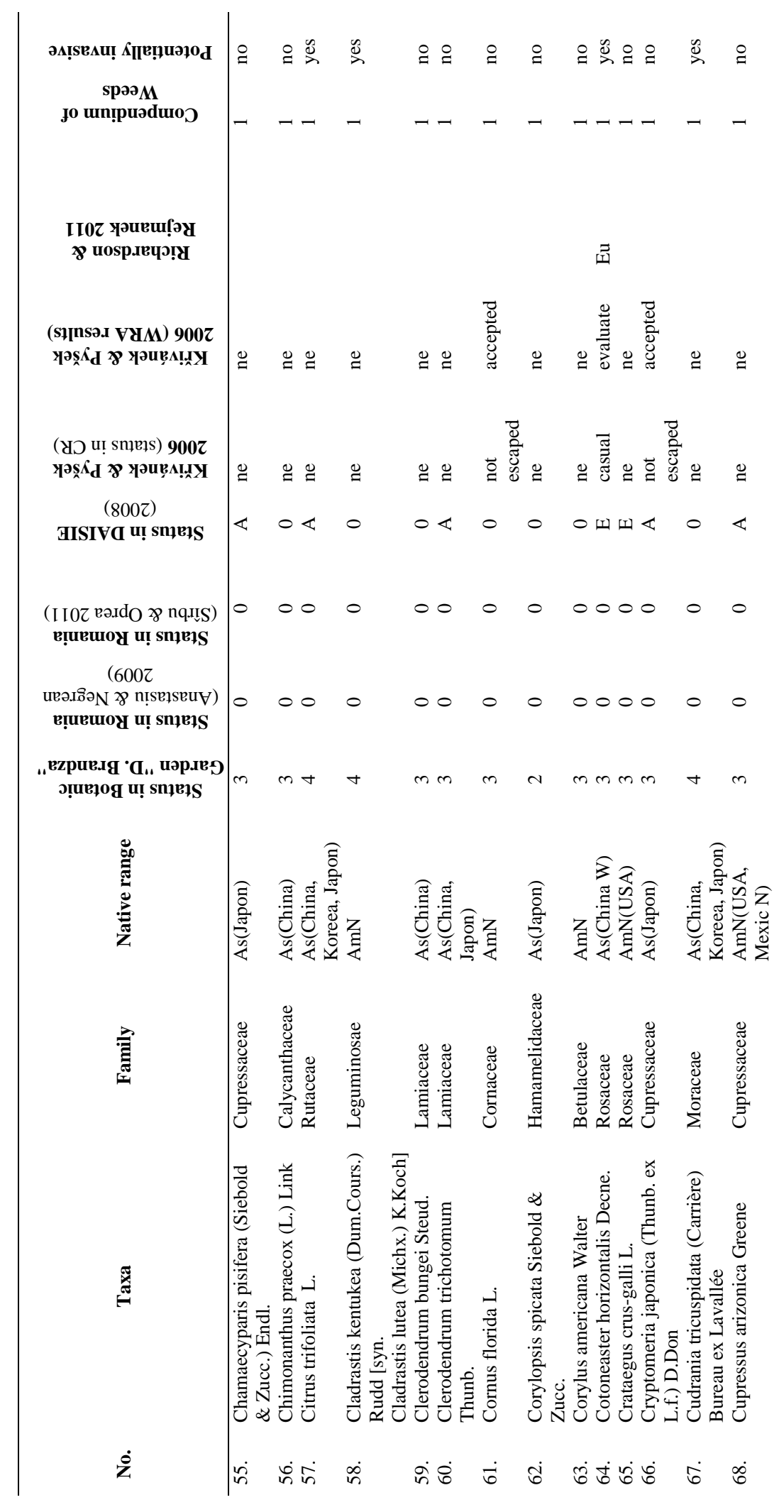




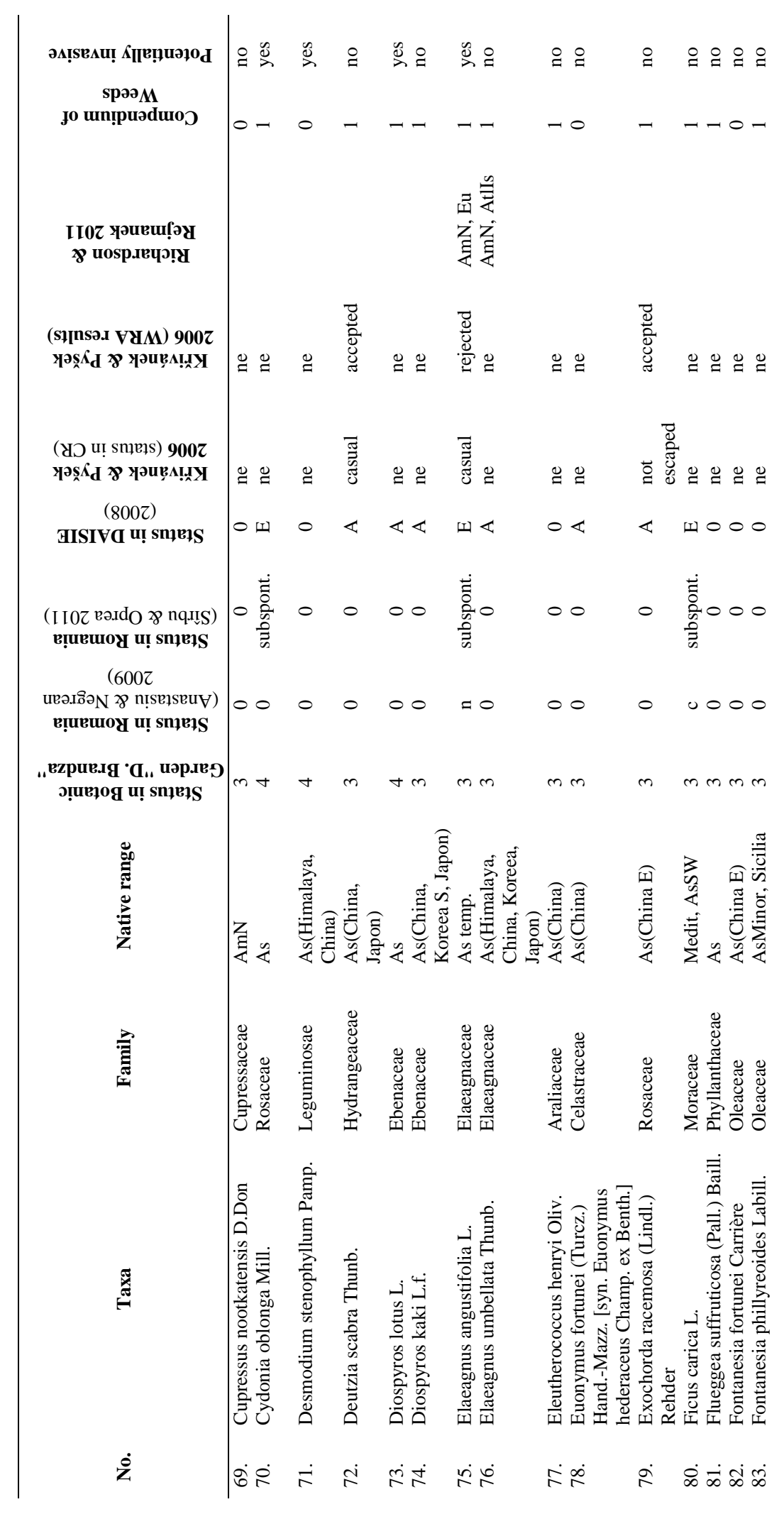




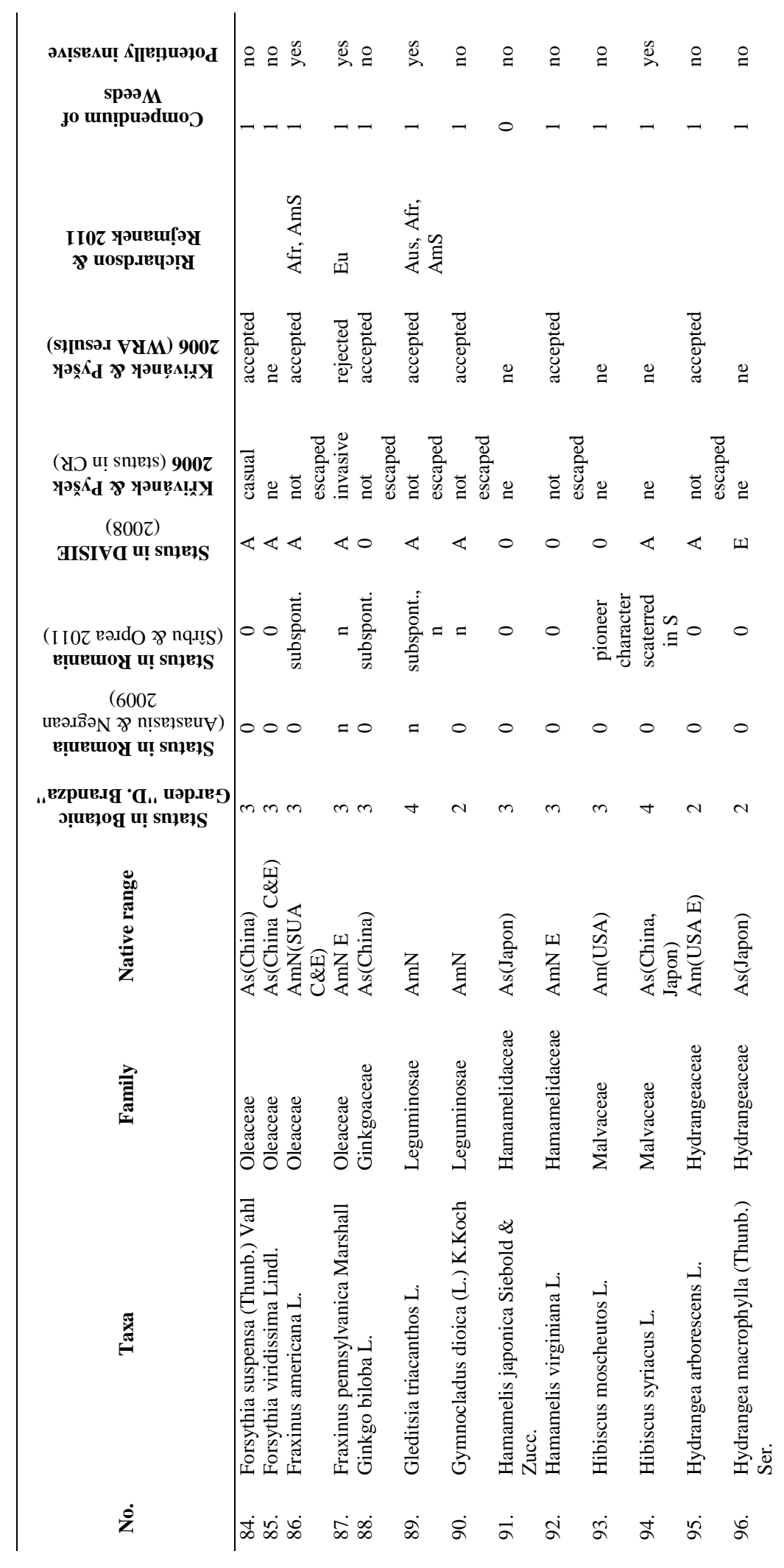




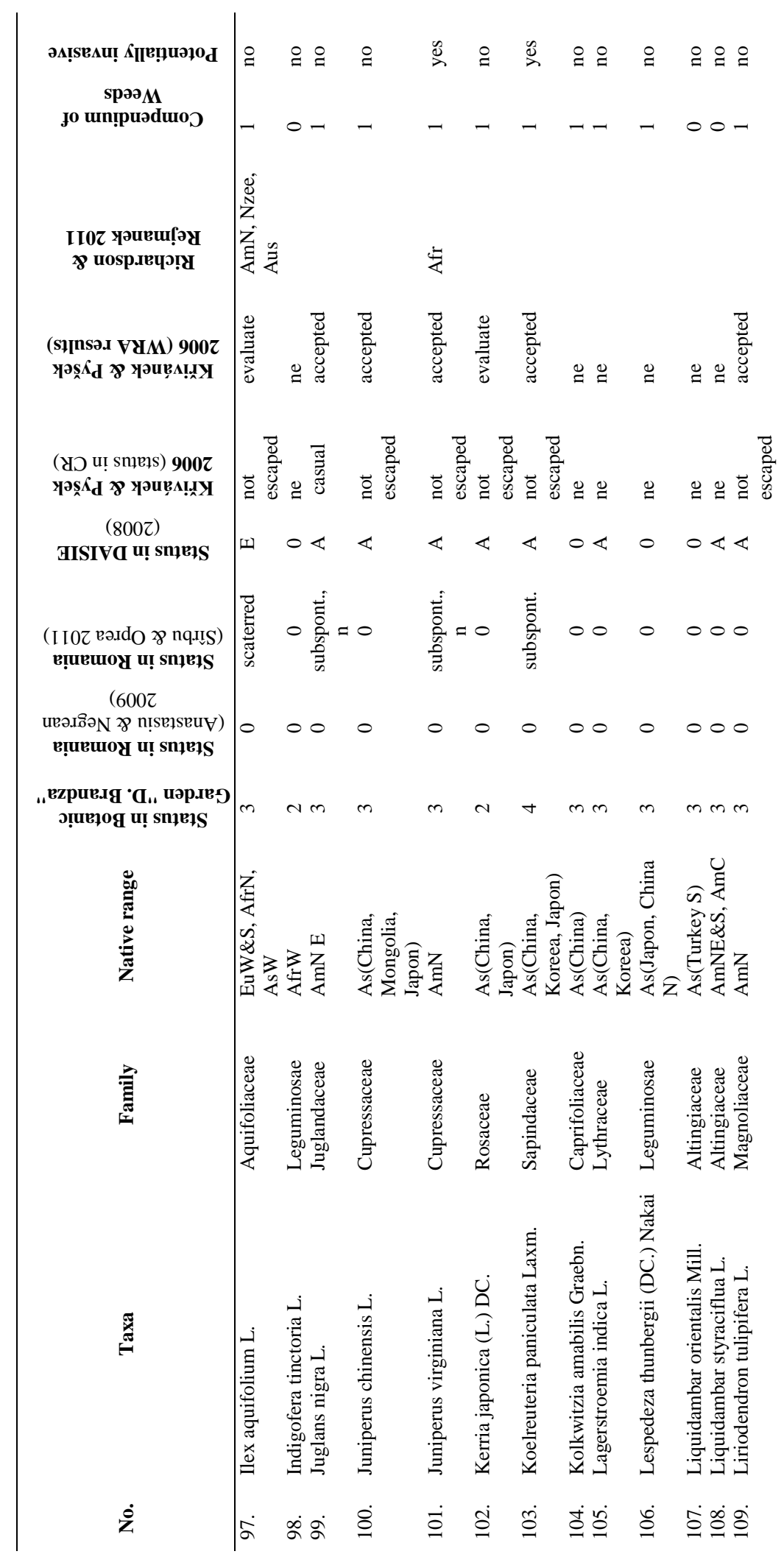




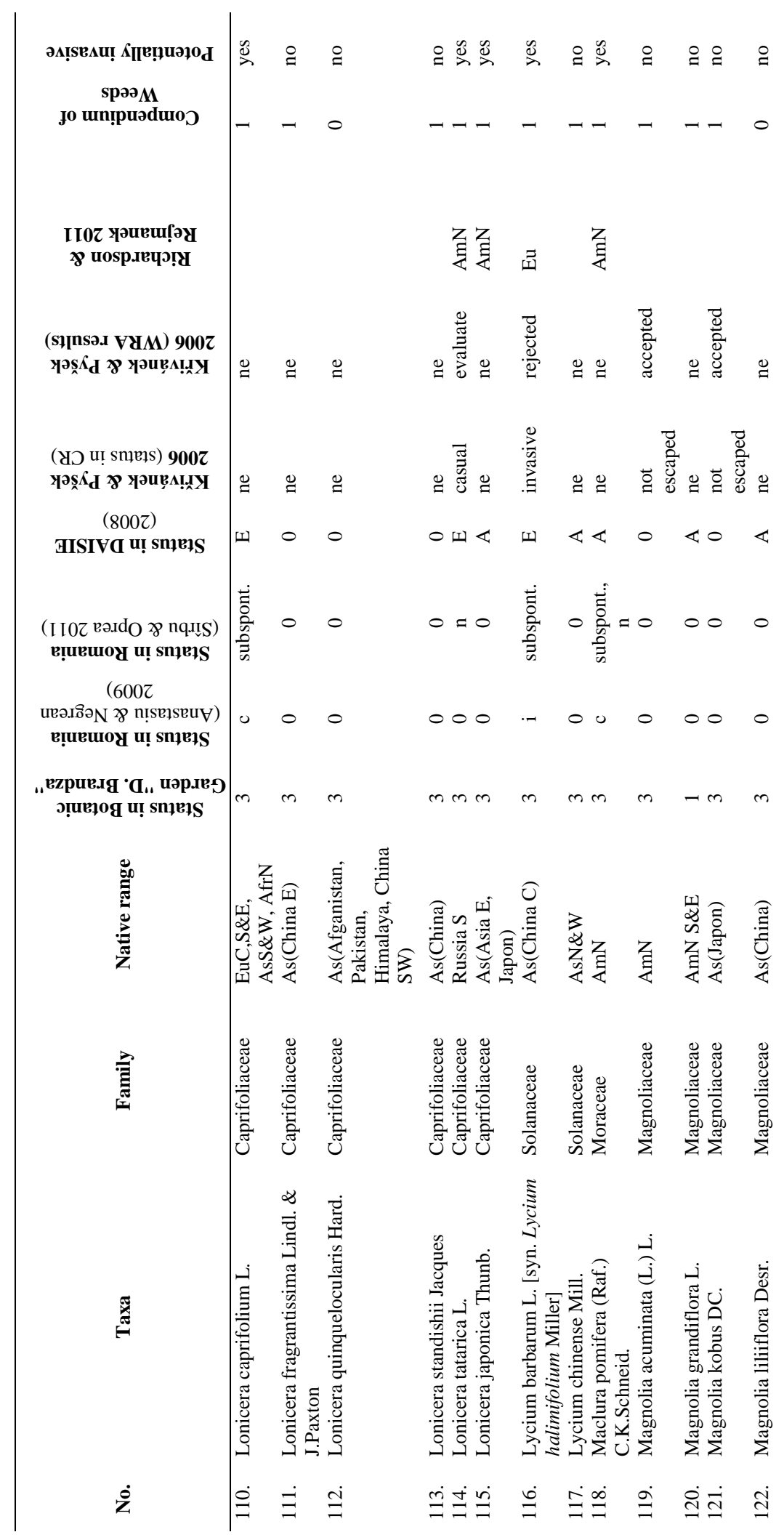




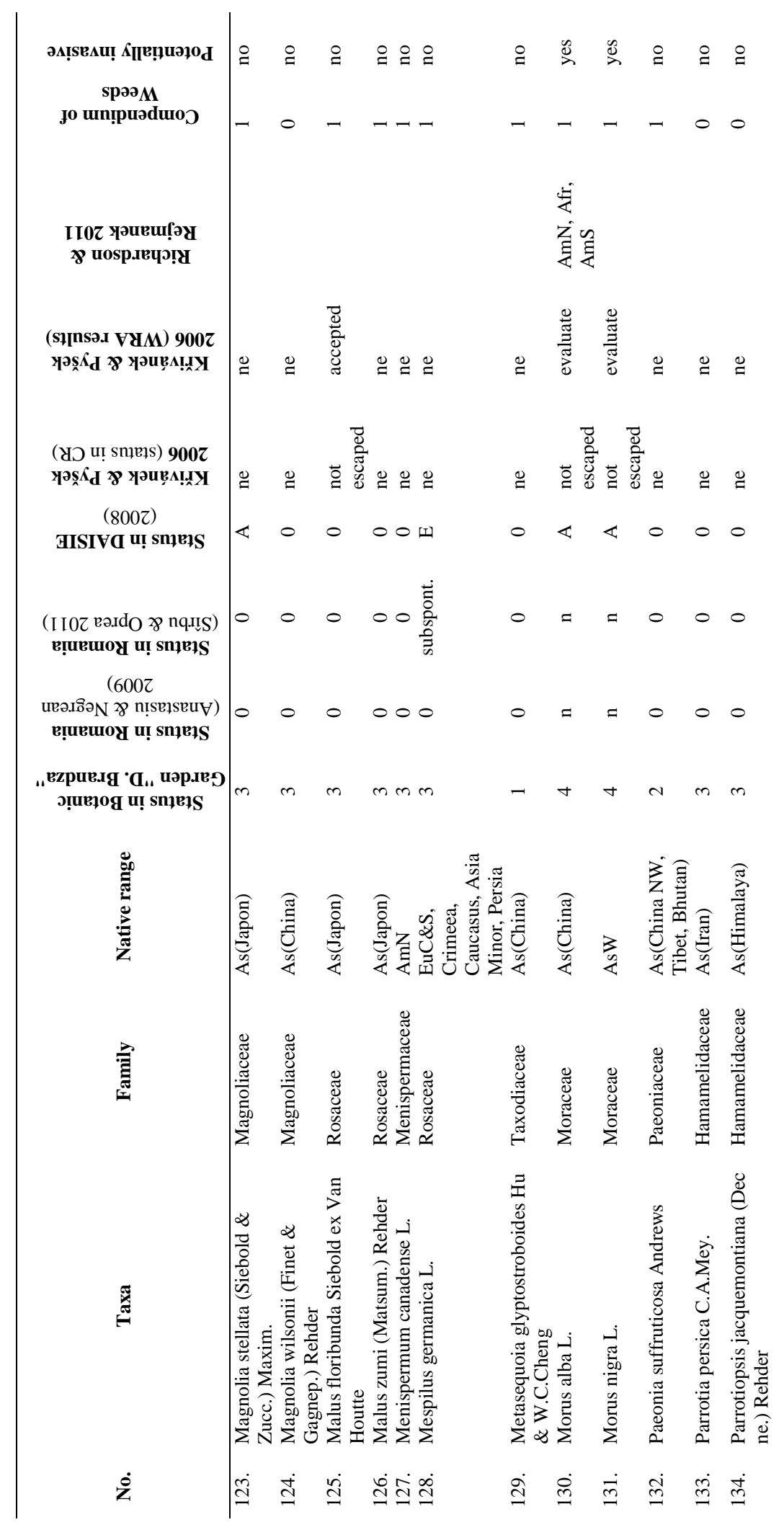




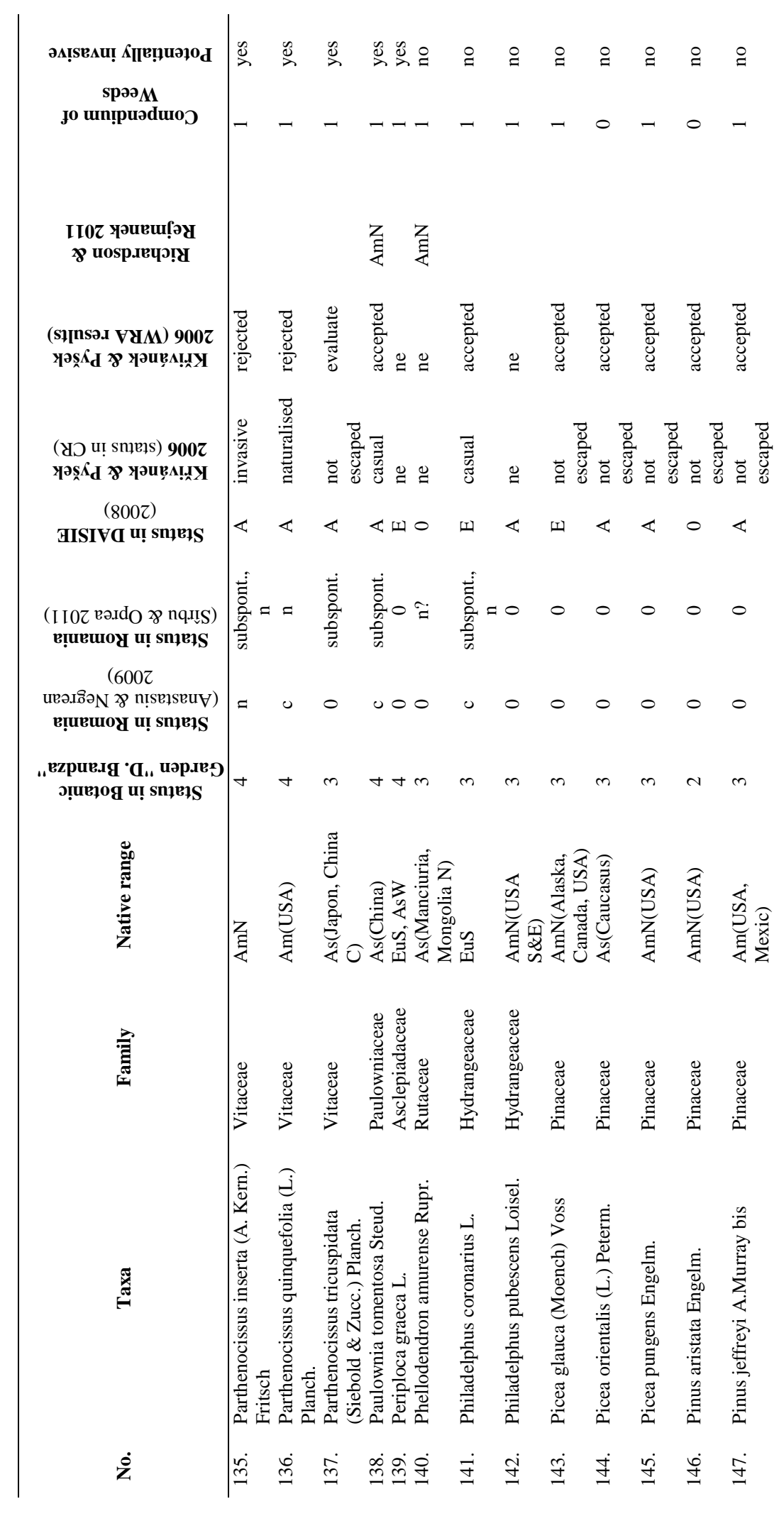




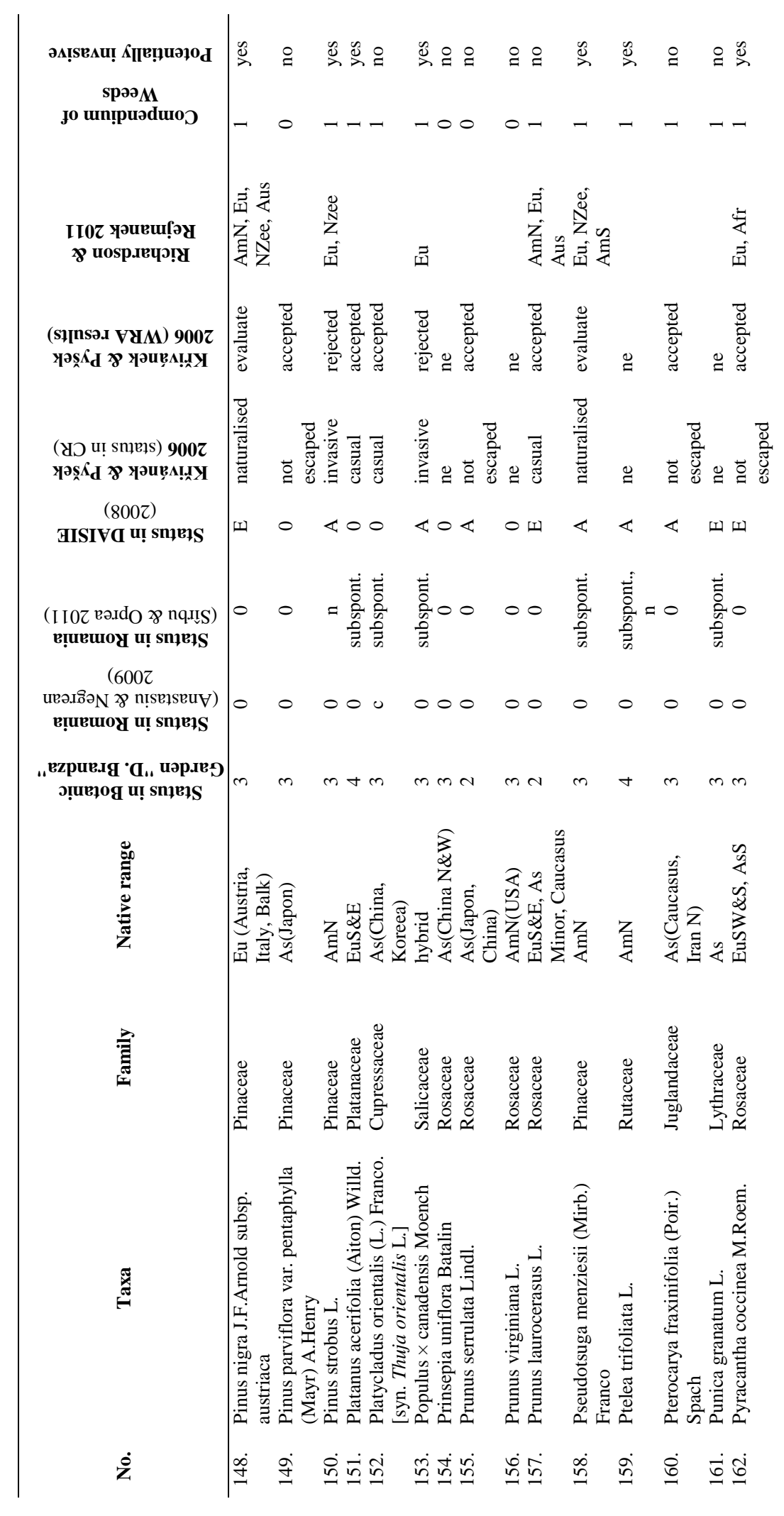




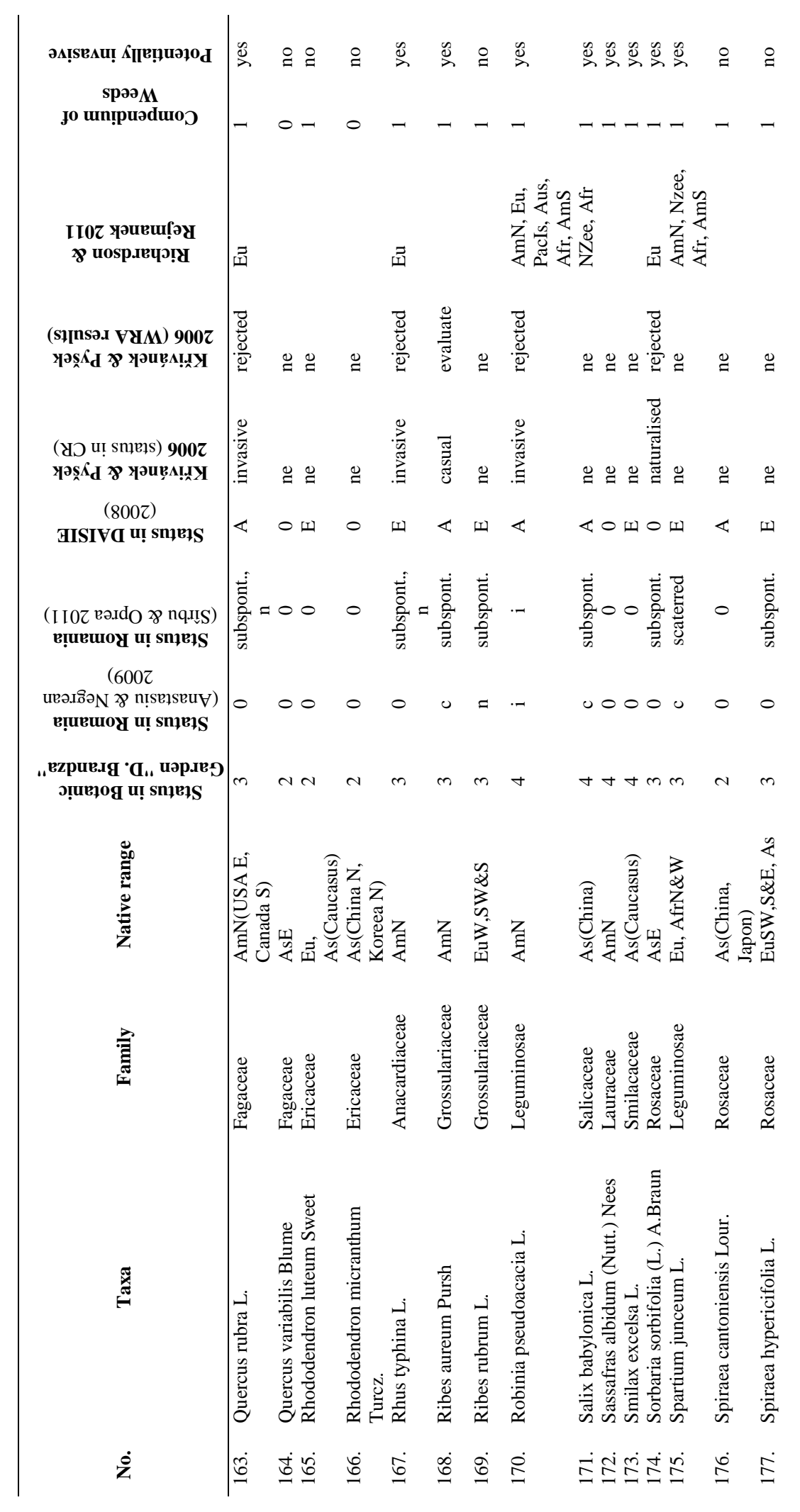




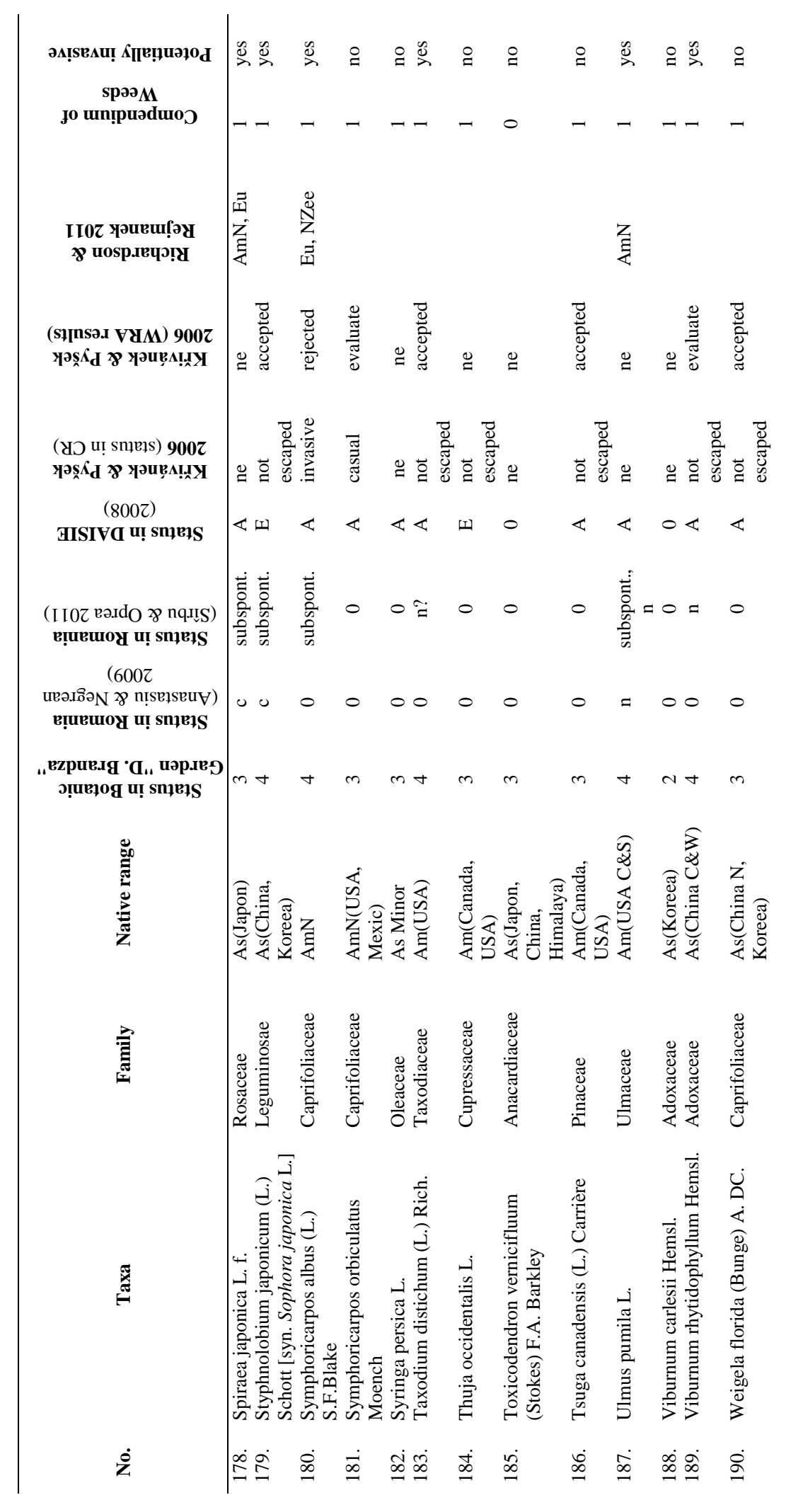




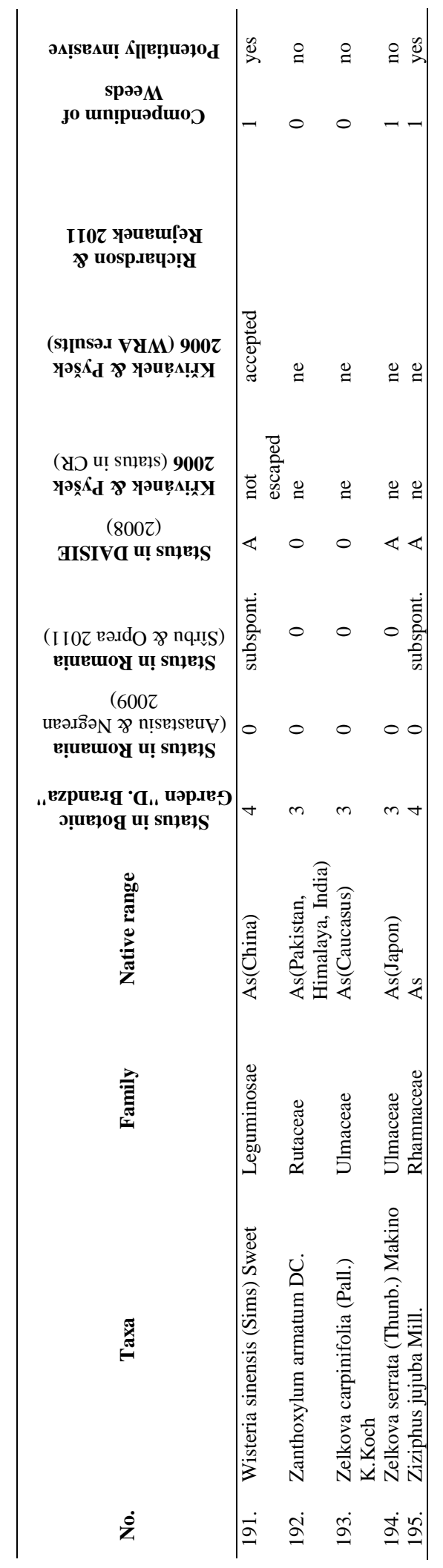

